\title{
E-LEARNINGOVÁ PODPORA PRO VÝUKU MEZINÁRODNÍ KLASIFIKACE FUNKČNÍCH SCHOPNOSTÍ, DISTABILITY A ZDRAVÍ (MKF)
}

\author{
Jana Kupková, Hana Matlasová, Marek Zeman \\ ISSN 1212-4117 \\ Jihočeská univerzita v Českých Budějovicích, Zdravotně sociální fakulta, katedra klinických oborů
}

12: $220-225,2010$

\begin{abstract}
ÚVOD
Na Zdravotně sociální fakultě Jihočeské univerzity v Českých Budějovicích byla vytvořena e-learningová podpora pro výuku Mezinárodní klasifikace funkčních schopností, disability a zdraví (MKF) v rámci předmětu Ucelená rehabilitace. Tento program byl vytvořen za finanční podpory projektu Fondu rozvoje vysokých škol (FRVŠ). Název projektu byl: Zkvalitnění výuky předmětu Ucelená rehabilitace, který byl řešen na Zdravotně sociální fakultě v Českých Budějovicích v průběhu roku 2009.

Prostřednictvím e-learningové podpory mají studenti možnost se seznámit se strukturou, posláním a cíli klasifikace MKF a její aplikací do klinické praxe. Díky názorným príkladům mohou porozumět systému kódování funkční schopností rehabilitanta. K dispozici jsou pro studenty také multimediální prvky (prezentace). Získané znalosti si mohou studenti následně ověřit procvičovacím testem a zadanými úkoly.
\end{abstract}

\section{Mezinárodní klasifikace funkčních schopností, disability a zdraví (MKF)}

Mezinárodní klasifikace funkčních schopností, disability a zdraví (ICF - International Classification of Functioning, Disability and Health) je hodnocení, které vypracovala Světová zdravotnická organizace (WHO). Členské státy EU prijaly v květnu 2001 tuto klasifikaci jako základní filozofii a politiku rehabilitace osob se zdravotním postižením (ICF, 2001; Stucki et al., 2002; Leonardi et al., 2005; Lippert-Grüner, 2005).

Mezinárodní klasifikace funkčních poruch, disability a zdraví patři mezi poměrně komplikované a obsáhlé klasifikace. Právě obsáhlost a komplikovanost její konstrukce může být příčinou, že ani za devět let od její ratifikace naší republikou doposud nenašla praktického využití ani širšího povědomí. Reforma zdravotně sociální oblasti s touto klasifikací však i nadále počítá, a proto by každý zdravotně sociální pracovník měl mít alespoň základní znalosti umožňující orientaci v této problematice (Pfeiffer, 2009).

Česká republika se dočkala knižního vydání překladu této klasifikace až v roce 2008 díky úsilí prof. Pfeiffera a doc. Švestkové z Kliniky rehabilitačního lékařství 1 . LF UK a VFN v Praze. Klasifikace MKF byla v ČR vydána Národní radou osob se zdravotním postižením, za podpory MZ ČR a MPSV ČR (Pfeiffer, Švestková, 2008).

$\mathrm{V}$ současné době se připravuje koncepce používání MKF v České republice. Praktické používání MKF v České republice by mělo podle slov prof. Pfeiffera postupně začít od r. 2010. Nejprve se budou provádět školení lékařu lékařské posudkové služby a další odborné veřejnosti. Jak uvádí Čeledová (2008): „Reforma a stabilizace činnosti lékařské posudkové služby je spojena s modernizací systému sociální ochrany a státní správy, ale také úzce souvisí se vzděláváním posudkových lékařů rezortu Ministerstva práce a sociálních věcí ČR.“

\section{MKF a MKN}

Na rozdíl od stále používané Mezinárodní klasifikace nemocí, MKN - 10. revize (ICD - International Classification of Diseases), která kóduje chorobný stav člověka, popisuje MKF situaci člověka $\mathrm{v}$ řadě okolností vztahujících se $\mathrm{k}$ jeho aktuálnímu zdravotnímu stavu (Švestková, Angerová, 2006). Dvě osoby se stejnou nemocí (dle $\mathrm{MKN}$ ) totiž mohou mít různý stupeň svých funkčních schopností (dle MKF). Jinými slovy stejná diagnóza může mít pro různé lidi zcela odlišné následky (např. s ohledem na jejich momentální sociální situaci) (Švestková et al., 2008). Na novou klasifikaci v České republice pro potřeby zdravotnictví a sociální oblasti pou- 
kazuje rovněž Bruthansová et al. (2009): „Tato publikace by se měla stát nezbytnou pro všechna rehabilitační centra, posudkové komise sociálního zabezpečení a pro všechny zdravotníky i veřejné činitele, jejichž pracovní náplň se týká zdravotně sociální a pracovní problematiky osob se zdravotním postižením.“

Cílem klasifikace MKF je vytvořit jednotný a standardizovaný popisný nástroj pro hodnocení komplexního stavu člověka. Klasifikace byla vyvinuta pro zlepšení komunikace mezi medicínskými obory, systémem sociálního zabezpečení, výzkumnými oblastmi sociální politiky a další širokou odbornou veřejností (Pfeiffer, Švestková, 2008; Pfeiffer, 2009).

Pro pacienta zapojeného do rehabilitace se podle klasifikace MKF použivá nový termín rehabilitant (WHO, 2001). Rehabilitace se týká nejen lidí, kteří v důsledku získaného onemocnění či úrazu byli vyřazeni ze svého každodenního života, ale i jedinců, kteří se s postižením narodili nebo s postižením žijí od útlého věku.

\section{Rehabilitace}

Rehabilitace je novolatinský pojem, který byl zaveden v 19. století a znamenal léčebné postupy vedoucí $\mathrm{k}$ návratu do stavu funkční schopnosti (Votava, 2005). V posledních letech se mění pohled na pojetí rehabilitace a neustále se obnovuje a upravuje terminologie $\mathrm{v}$ této oblasti. Dř́ve byla rehabilitace chápána spíše ve smyslu zdravotnickém, a to především jako fyzioterapie. Votava (2005) uvádí, že v roce 1951 byla rozhodnutím Ministerstva zdravotnictví přejmenována všechna fyziatrická oddělení na rehabilitační, což způsobilo, že je rehabilitace v pojetí léčebné i ucelené rehabilitace u nás dostatečně zajištěna. Votava ř́ká, že z této doby se u nás užívá vžitý omyl, že rehabilitace je lékařský obor, který se zabývá pouze problémy porušené motoriky a léćbou bolestivých syndromů.

Rehabilitace dnes již není chápána pouze jako zdravotnická aktivita - ve smyslu fyzioterapie, ale jako interdisciplinární obor, který zahrnuje péči nejen zdravotnickou, ale také sociálněprávní a pedagogicko-psychologickou (Jankovský, 2001; Jankovský et al., 2005). Také Jesenský (1995) člení rehabilitaci na čtyři hlavní složky - rehabilitaci léčebnou, pracovní, sociální a pedagogickou. Je prosazována koncepce multidisciplinární týmové spolupráce. Dle Votavy (2005) multidisciplinární tým představuje skupi- nu odborníků, kteří v rámci rehabilitační medicíny vzájemně spolupracují a dosahují tak společných rehabilitačních cílů u jednotlivých pacientů. Jak zdůrazňují Švestková a Pfeiffer (2009, s. 268-271), „základem moderní rehabilitace je individuálně zaměřený multidisciplinární tým, který klade důraz na včasné zahájení, vypracování rehabilitačního plánu s cílem dosáhnout optimální kvality života $\mathrm{v}$ co nejkratším čase a s efektivními náklady“. Jankovský (2007) zdůrazňuje partnerský vztah mezi všemi odborníky navzájem, ale také vůči rodičům a rodině člověka se zdravotním postižením. Zdůrazňuje to, aby vztahy mezi členy týmu byly založeny na vzájemné důvěře, porozumění, sdílení a solidaritě. U všech pracovníků multidisciplinárního týmu se předpokládá vysoká odbornost a profesionalita, nesmí chybět také lidský rozměr (Jankovský, 2007).

V České republice od 1. 1. 2007 nabyl platnosti zákon č. 108/ 2006 Sb., o sociálních službách, který upravuje podmínky poskytování a podpory fyzickým osobám $\mathrm{v}$ neprríznivé sociální situaci prostřednictvím sociálních služeb a př́spěvku na péči (ÚZ Sociální zabezpečení, 1997; zákon č. 108/2006 Sb.). Jde o určitou míru umožnění aplikace klasifikace $\mathrm{MKF}$ v České republice, a to hlavně z hlediska deinstitucionalizace, tedy komunitní rehabilitace a sociálních služeb (Community based rehabilitation and health care referral services, 1994).

\section{E-learning}

V současné době je e-learning velice diskutovaným pojmem, ukazuje se, že je pro studenty vhodné doplnit klasickou výuku pomocí e-learningové podpory $\mathrm{k}$ předmětu. Touto formou byla doplněna i výuka předmětu Ucelená rehabilitace na Zdravotně sociální fakultě JU v Českých Budějovicích, v rámci které jsme se zaměřli právě na e-learningovou oporu výuky MKF.

Výhody e-learningu uvádí Nocar et al. (2004) $\mathrm{v}$ publikaci E-learning v distančním vzdělávání následovně:

- vyšší efektivnost výuky;

- aktuálnost informací;

- př́stup $\mathrm{k}$ materiálům odkudkoliv;

- prístup $\mathrm{k}$ materiálům kdykoliv;

- zapamatovatelnější forma informací;

- větší možnost testování znalostí; 
- vyšší míra interaktivity;

- nižší náklady na vzdělávání;

- překonání př́ípadných zdravotních bariér.

E-learning především umožňuje využívání bourlivě se rozvíjející IT technologie a techniky vưbec $\mathrm{k}$ neustálému zkvalitňování výuky. V současné době má program Moodle, který je využíván $\mathrm{v}$ rámci internetových vzdělávacích kurzů na ZSF JU, na světě asi 15 milionů uživatelů. Jedná se o druhý nejpoužívanější e-learningový program na světě (Šembera, 2008).

Cílem e-learningové podpory pro výuku MKF na Zdravotně sociální fakultě JU je seznámit studenty se strukturou, posláním a cíli klasifikace MKF, včetně uvedení praktických prríkladů kódování, dále podpořit výuku předmětu Ucelená rehabilitace a napomoci snadnější orientaci studentů $\mathrm{v}$ dané problematice, zlepšit vzájemnou komunikaci mezi studenty a vyučujícími prostřednictvím zpětné vazby, vyhodnotit výsledky testů. $\mathrm{V}$ rámci předmětné podpory je možnost aktualizovat kurz v kontextu platných právních norem, resp. př́stupů $\mathrm{v}$ problematice MKF, posuzování zdravotně sociálního stavu $\mathrm{v}$ pojetí moderní rehabilitace.

Studenti jsou v e-learningovém programu seznamováni se základní terminologií a novou koncepcí moderní rehabilitace dle klasifikace MKF, s novými pojmy jako např. „,rehabilitant“, „disabilita“, ,,aktivita a participace“ a jejich definicí podle MKF.

$\mathrm{V}$ rámci opory předmětu Ucelená rehabilitace bylo vytvořeno následujících 14 témat, kde se 2 témata týkají konkrétně klasifikace MKF (viz téma č. 2 a č. 4).

\section{Témata e-learningové opory předmětu:}

1. Rehabilitace jako ucelený systém

2. MKF a právní ukotvení

3. Osoba se zdravotním postižením

4. Jak pracovat s MKF, přehled komponent MKF, klasifikace dle MKF

5. Léčebná rehabilitace, rehabilitační tým, kompetence, cíle

6. Sociální rehabilitace

7. Pedagogická rehabilitace

8. Pracovní rehabilitace

9. Osobnost zdravotně postiženého a možnost jejího ovlivnění

10. Technická hlediska v ucelené rehabilitaci
11. Př́klady ucelené rehabilitace

12. Problematika rehabilitace vybraných věkových skupin - senioři

13. Problematika rehabilitace vybraných věkových skupin - děti

14. Nestátní neziskové organizace v systému péče o občany se zdravotním postižením

Témata e-learningu byla vytvořena podle sylabů předmětu Ucelená rehabilitace. Vstup do kurzu je možný na odkazu http:// moodle.zsf.jcu.cz/ nebo na hlavní stránce fakulty http://www.zsf.jcu.cz. v rubrice Odkazy e-Learning ZSF (Moodle).

V kategorii kurzů pod odkazem Katedra klinických oborů 09/10 lze nalézt kurz Ucelené rehabilitace. Po zadání př́stupového hesla se zapsaní studenti dostanou na stránky kurzu.

$\mathrm{K}$ jednotlivým tématům bylo vytvořeno shrnutí, úkol a testové otázky - $\mathrm{k}$ možnosti procvičení probírané problematiky. Studenti mají možnost komunikovat s vyučujícími předmětu, diskutovat s nimi i s ostatními studenty navzájem. Součástí kapitol jsou odkazy na odbornou literaturu zabývající se daným tématem.

Prostřednictvím e-learningu se tak mohou studenti připravovat na výuku z kteréhokoli místa připojeného do mezinárodní sítě internet. Velké využití e-learningové formy studia je především u studentů kombinované formy studia. E-learning je nyní připraven $\mathrm{k}$ zápisu studentů do kurzu Ucelená rehabilitace pro letní semestr akademického roku 2009/2010. Od vyučujícího předmětu dostanou studenti prŕistupové heslo pro vstup do kurzu.

Součástí vzdělávací opory je návod, jak kódovat podle klasifikace MKF zdravotní a sociální situaci člověka s jakoukoliv disabilitou. Názorná, barevně provedená verze praktického kódování $\mathrm{MKF}$ je v elektronické podobě (formát pdf) informativní príručky $\mathrm{k}$ dispozici na stránkách e-learningového kurzu nebo také na webových stránkách (http://www.zsf.jcu.cz/Members/ zemanm03/Publikace):

\section{Struktura klasifikace MKF}

Jakýkoliv stav související se zdravím je možné definovat uvedením příslušného kódu ze čtyř následujicích dimenzí člověka:

1. Tělesné funkce (Body Functions) $-\mathbf{b}$

2. Tělesné struktury (Body Structures) - $\mathbf{s}$ 
3. Aktivity a participace (Activities and Participation) $-\mathbf{d}$

4. Faktory prostředí (Environmental Factor) - e

Kódy v jednotlivých dimenzích mohou být jednostupňové (např. b7, s4, d5, ...), dvoustupňové (např. b710, s430, d540, ...) i tř́istupňové (např. b7102, s4301, d5403, ...) s ohledem na to, jak je možné být $\mathrm{v}$ daném prrípadě konkrétní.

Použití kteréhokoliv kódu klasifikace musí být dále doprovázeno přidáním jednoho až tří tzv. kvalifikátorů. Kvalifikátory určují stupeň zdraví, resp. závažnost problému. Jsou uváděny jako jedno nebo více čísel za tečkou (nebo dělítkem) každého kódu. Bez prriřazení kvalifikátoru nemá kód smysl. Stav člověka se hodnotí za posledních 30 dní.

\section{Kvalifikátory MKF}

Kvalifikátory určují stupeň zdraví nebo závažnost problému. Jsou uváděny jako jedno nebo více čísel za tečkou (nebo dělítkem) v každém kódu.

Použití kteréhokoliv kódu klasifikace musí být doprovázeno přinejmenším jedním kvalifikátorem.

\begin{tabular}{|l|l|c|}
\hline xxxx.0 & žádná, zanedbatelná & $0-4 \%$ \\
\hline xxxx.1 & lehká, nepatrná & $5-24 \%$ \\
\hline xxxx.2 & střední, mírná, snesitelná & $25-49 \%$ \\
\hline xxxx.3 & těžká, vysoká, extrémní & $50-95 \%$ \\
\hline xxxx.4 & úplná, totální & $96-100 \%$ \\
\hline xxxx.8 & nespecifická & \\
\hline xxxx.9 & nelze aplikovat & \\
\hline
\end{tabular}

(Pfeiffer, 2008; Zeman, 2010)

Kvalifikátory jsou svým rozsahem stejné pro všechny komponenty i domény. Pouze u Tělesných struktur mohou být více specifikovány (rozsah, původ a lokalizace poruchy), u Aktivit a participací je rozlišován kvalifikátor výkonnosti a kapacity. A u Faktorů prostředí kvalifikátor určuje rozsah, ve kterém je faktor bud' bariérový, nebo facilitační (př́klady viz dále).

\section{Kvalifikátor tělesných funkcí (b)}

b7302 Síla svalová jedné poloviny těla

b7302._ rozsah poruchy (první kvalifikátor)

Příklad: b7302. 3 Těžká porucha síly svalové na jedné polovině těla (50-95\%).

\section{Kvalifikátory tělesných struktur (s)}

Rozsah poruchy (první kvalifikátor)

Původ poruchy (druhý kvalifikátor)

Lokalizace poruchy (třetí kvalifikátor)

s120.
Př́klad: s 120. 435 Mícha a pridružené struktury. Úplná porucha, přídatná část, dorzálnè.

\section{Kvalifikátory aktivit a participací (d)}

Kvalifikátor výkonnosti (první kvalifikátor) Kvalifikátory kapacity (druhý kvalifikátor) d4500.

Príklad:

d4500 Chi̊ze na krátké vzdálenosti.

d4500.3_ Mírné omezení při výkonu chůze na krátké vzdálenosti.

d4500._3 Těžké omezení kapacity chưze na krátkou vzdálenost.

\section{Kvalifikátory faktorů prostředí (e)}

Musí být chápány pro každou komponentu funkční schopnosti. Mají být kódované z perspektivy osoby, jejíž situace je popisována. Napŕíklad okraje chodníku bez rozdílu výšky mohou být facilitační pro uživatele vozíků, ale bariérou pro osoby nevidomé. 


\begin{tabular}{|llll|}
\hline \multicolumn{3}{|c|}{ Samotný bod . Označuje bariéru, znaménko + označuje facilitaci. } \\
\hline & & & \\
\hline xxx.0 & žádná bariéra & $\mathrm{xxx}+0$ & žádná facilitace \\
\hline xxx.1 & lehká bariéra & $\mathrm{xxx}+1$ & lehká facilitace \\
\hline xxx.2 & střední bariéra & $\mathrm{xxx}+2$ & střední facilitace \\
\hline xxx.3 & těžká bariéra & $\mathrm{xxx}+3$ & těžká facilitace \\
\hline xxx.4 & úplná bariéra & $\mathrm{xxx}+4$ & úplná facilitace \\
\hline xxx.8 & bariéra nespecifická & $\mathrm{xxx}+8$ & facilitace nespecifická \\
\hline xxx.9 & nelze aplikovat & $\mathrm{xxx}+9$ & nelze aplikovat \\
\hline
\end{tabular}

(Pfeiffer, 2008; Zeman, 2010)

Př́iklad:

el152.3 Těžká bariéra týkajicí se konstrukce budov (bydlí ve druhém patře bez výtahu).

e1101+4 Úplná facilitace prostřednictvím léků (např. u kardiaka, kdyby neužival léky, tak müže dojít k zástavě srdce).

\section{Př́klad praktické aplikace MKF}

Muž, 52 let.

\section{Klasifikace dle MKN:}

I42.0 (dilatační kardiomyopatie)

Klasifikace dle $\boldsymbol{M K F}$ (Zeman, 2010): s4100.288 (srdce, středně těžká nespecifická porucha)

b4552.2 (unavitelnost při cvičení, středně těžká porucha)

b2801.2 (vnímání bolesti na hrudníku, stř̌edně těžká porucha)

d450.23 (chůze, středně těžká porucha ve výkonu, těžká porucha v kapacitě)

d4751.13 (ř́zení automobilu, lehká porucha ve výkonu, těžká porucha v kapacitě)

d510.23 (samostatné mytí, středně těžká porucha ve výkonu, těžká porucha v kapacitě)

e1101+4 (léky, úplná facilitace)

e1152.3 (technologie a konstrukce budov, těžká bariéra)

e310+4 (nejbližší rodina, úplná facilitace)

Přehled všech kódů dvoustupňové a třístupňové klasifikace je uveden $\mathrm{v}$ českém překladu ICF „Mezinárodní klasifikace funkčních schopností, disability a zdravi“" nebo $\mathrm{v}$ originále na webových stránkách WHO na http://apps.who.int/classifications/icfbrowser/

Studenti mohou pro studium využít manuály MKF, které byly zakoupeny $\mathrm{v}$ dostatečném množství z finančních prostředků FRVŠ. Publikace MKF jsou umístěny $\mathrm{v}$ knihovně ZSF JU. Seznam další zakoupené literatury z projektu FRVŠ je umístěn na titulní straně po vstupu do předmětného kurzu.

\section{ZÁVĚR}

$\mathrm{Na}$ Zdravotně sociální fakultě Jihočeské univerzity $\mathrm{v}$ Českých Budějovicích byla vytvořena elearningová opora pro výuku Mezinárodní klasifikace funkčních schopností, disability a zdraví (MKF) v rámci předmětu Ucelená rehabilitace. Tento program byl vytvořen za finanční podpory projektu Fondu rozvoje vysokých škol, který byl řešen na Zdravotně sociální fakultě v Českých Budějovicích v průběhu roku 2009.

Prostřednictvím e-learningové podpory mají studenti možnost se seznámit se strukturou, posláním a cíli klasifikace MKF. Díky názorným př́kladům mohou porozumět systému kódování funkční schopnosti rehabilitanta. Získané znalosti si mohou ověrit procvičovacím testem.

Filozofii klasifikace MKF přijala Evropská unie (a tedy i Česká republika) jako základ pro politiku moderní rehabilitace a zavázala se, že ji bude použivat při hodnocení $\mathrm{v}$ rehabilitaci. Je tedy potřebné se s klasifikací seznamovat a zařazovat ji do výuky na školách se zdravotním a sociálním zaměřením. 
Velký přínos vidíme $\mathrm{v}$ zakoupení publikací klasifikace MKF, která je od 1. 1. 2010 zakotvena v legislativě České republiky (Česká republika dosud jako jediná ze států Evropské unie neměla MKF uvedenou $v$ legislativě) a pripravují se pořádat školení a kurzy pro seznamování se s koncepcí této klasifikace. Studenti se tak mohou díky zakoupené literatuře seznamovat s používáním a principy klasifikace $\mathrm{MKF}$ jako jedni z prvních ze studentů škol zdravotně sociálního zaměření.

* Vypracováno za finanční podpory FRVŠ, název projektu: Zkvalitnění výuky predmětu Ucelená rehabilitace, č. 205-201-0959 FRV $\check{S}$

\section{LITERATURA}

BRUTHANSOVÁ, D. et al.: Nová klasifikace nemoci a zdraví. In: Česká geriatrická revue, č. 2, roč. 2009.

Community based rehabilitation and health care referral services: A guide for programme managers. Rehabilitation. World Health Organization, 1994.

ČELEDOVÁ, L.: Celoživotní vzdělávání posudkových lékařu. Tempus medicorum, 2008, roč. 17, č. 9.

The International Classification of Functioning, Disability and Health. WHO, 2001.

JANKOVSKÝ, J.: Ucelená rehabilitace dětí s tělesným a komb. postižením. Praha Triton, 2001, s. 16.

JANKOVSKÝ, J.: Možnosti a podmínky mezioborové spolupráce v rámci multidisciplinárního týmu. In: Sociální práce, 2007, č. 1, s. 97-105.

JANKOVSKÝ, J., PFEIFFER, J., ŠVESTKOVÁ, O.: Vybrané kapitoly z uceleného systému rehabilitace. České Budějovice: ZSF JU, 2005, s. 103.

JESENSKÝ, J.: Uvedení do rehabilitace zdravotně postižených. Praha, Univerzita Karlova, 1995, s. 159.
LEONARDI, M., PISSONI, C., RAGGI, A., AJOVALASIT, D., CATTONI, D.: Measuring Health and Disability in Europe: Supporting policy development - MHADIE. Milano: Instituto neurologico C. Besta, 2005, pp. 6-10. LIPPERT-GRÜNER, M.: Neurorehabilitace. 1. vyd. Praha: Galén, 2005, s. 350.

NOCAR, D. et al.: E-learning v distančním vzdělávání. Olomouc: Univerzita Palackého, 2004, s. 15-16.

PFEIFFER, J.: Využití $M K F$. Přednáška na téma: Kvalita života a využití MKF. České Budějovice: Zdravotně sociální fakulta Jihočeské univerzity, 2009.

PFEIFFER, J., ŠVESTKOVÁ, O.: Mezinárodní klasifikace funkčních schopností, disability a zdraví. Praha: Grada, $2008,280 \mathrm{~s}$.

STUCKI, G., CIEZA, A., EWERT, T. et al.: Application of the International Classification of Functioning, Disability and Health (ICF) in Clinical Practice. Disabil Rehabil, 2002, 5, p. 281-282.

ŠEMBERA, R.: E-learning na ZSF JU. In: Quo vadis. Informační bulletin ZSF JU. 1/2008, s. 40.

ŠVESTKOVÁ, O., ANGEROVÁ, Y.: Rehabilitace v České republice. In: Florence: časopis moderního ošetrovatelství. Roč. II., č. 3., 2006, s. 23-25.

ŠVESTKOVÁ, O., PFEIFFER, J.: Funkční hodnocení (diagnostika) v rehabilitaci. In: Praktický lékař, 2009, roč. 89, č. 5. s. 268-271.

ŠVESTKOVÁ, O., PFEIFFER, J., KUPKOVÁ, J., MATLASOVÁ, H.: Mezinárodní klasifikace funkčních schopností, disability a zdraví WHO jako nástroj moderní rehabilitace. Praktický lékař, 2008, roč. 88, č. 3, s. 161164.

VOTAVA, J.: Ucelená rehabilitace osob se zdravotním postižením. Praha: Karolinum, 2005, s. 9-10.

WHO. International classification of functioning, disability and health: ICF short version. Geneva: WHO, 2001. $228 \mathrm{~s}$

ÚZ Sociální zabezpečení č. 617. Ostrava: Sagit, 2007, $256 \mathrm{~s}$ Zákon č. 108/2006 Sb., o sociálních službách.

ZEMAN, M.: ICF - Uživatelská príručka. [cit. 2010-0310] Dostupné z: http://www.zsf.jcu.cz/Members/ zemanm03/Publikace>. 